\title{
The Roles of School Principal in the Implementation of Character Education at Boarding School
}

\author{
Asmendri \\ Department of Islamic Studies, STAIN Batusangkar, Indonesia \\ E-mail: asmendri.25@gmail.com \\ DOI: http://dx.doi.org/10.15548/jt.v21i2.87
}

\begin{abstract}
The success or failures of educational institutions in the implementation of character education in boarding schools or madrasah is determined by its leaders. The school principal as a leader and educator should be a good model to all teachers and learners in the school. In other words, he or she will create a healthy school life, conducive and supportive school performance. There are seven principal's roles in implementing character building the school. He or she should has a clear vision, rely on more collaborative approach, responsive and proactive in responding to what is happening outside of school, be consistent in enforcing the rules, be active, give many social rewards, and create a variety of rides or activities that can develop pro-social skills and devotion of students.
\end{abstract}

Keywords: School principal, character education, Boarding School

\section{INTRODUCTION}

Character comes from the Greek word meaning "to mark" (tag) and focusing on how to apply the virtues in action or behavior every day. A person who behaves dishonestly, fraudulently, said to be cruel and greedy people who have bad character, while a well-behaved, honest and helpful to say as someone who has a good character/noble. Simply put, character education is everything to do that influences the character of the students that teacher teach. But to put in a more focused light, Lickona (1991) stated definition that "character education is the deliberate effort to help people understand, care about, and act upon core ethical values". When people think about the kind of character they want for their children, it is clear that they want their children to be able to decide what is right, care deeply about what is right, and then do what the children believe to be right, even in the face of pressure from without and with temptation from within.

The other definition of Character education refers to an ongoing and never ending process, resulting in continuous quality improvement. The goal is to realize the future of human figures that is brought by the cultural values of the nation. The word 'character' comes from Greek that means "to mark" (tag) and focusing on how to apply the virtues or everyday- life in action. A person, who behaves dishonestly and fraudulently, is said to be cruel and greedy and has bad character; while a well-behaved, honest and helpful person should be classified as having good character and noble man.

To be effective, character education must include all stakeholders in a school community and must permeate school climate and curriculum. Character education includes a broad range of concepts such as positive school culture, moral education, just communities, caring school communities, social-emotional learning, positive youth development, civic education, and service learning. All of these approaches promote the intellectual, social, emotional, and ethical development of young people and share a commitment to help young people become responsible, caring, and contributing citizens. Character education so conceived helps students to develop important human qualities such as justice, diligence, compassion, respect, and courage, and to understand why it is important to live by them. Quality character education creates an 
integrated culture of character that supports and challenges students and adults to strive for excellence. Husaini (2010) said that character education is not a process of memorizing exam materials, and techniques to answer. Character education requires habituation. Habituation to do good; habituation to be honest, knight; ashamed to cheat; ashamed of being lazy; shame to let a dirty environment. Character is not formed in an instant, but must be trained seriously and proportionate in order to achieve the ideal shape and strength.

Anxiety governments / leaders of the moral decline in national life is certainly very reasonable. in the West that strongly extolling freedom (liberalism), human rights, emancipation and tolerance must intervene into the world of education for the formation of character. They had also believe that schools have an important role in the development and character building to create a good society. Indonesia is not a secular state must be very interested in this.

No single script for effective character education exists, but there are some important guiding principles. Based on the practices of effective schools, the Eleven Principles of Effective Character Education form the cornerstone of Character Education Parnership or CEP's philosophy on how best to develop and implement high-quality character education initiatives. As broad principles that define excellence in character education, the 11 Principles serve as guideposts that schools and others responsible for youth character development can use to plan and evaluate their programs. CEP (2010) stated The 11 Principles are: (1) The school community promotes core ethical and performance values as the foundation of good character, (2) The school defines "character" comprehensively to include thinking, feeling, and doing, (3) The school uses a comprehensive, intentional, and proactive approach to character development, (4) The school creates a caring community, (5) The school provides students with opportunities for moral action, (6) The school offers a meaningful and challenging academic curriculum that respects all learners, develops their character, and helps them to succeed, (7) The school fosters students' self-motivation, (8) The school staff is an ethical learning community that shares responsibility for character education and adheres to the same core values that guide the students, (9) The school fosters shared leadership and long-range support of the character education initiative, (10) The school engages families and community members as partners in the character-building effort, and (11) The school regularly assesses its culture and climate, the functioning of its staff as character educators, and the extent to which its students manifest good character.

Megawangi, in Mulayasa (2011:5) has stated nine pillars of noble character that should be used as reference for character education both in and outside of school, namely (1) God's love and truth, (2) responsibility, discipline and independent, (3) trust, (4) respect and courtesy, (5) compassion, caring, and cooperation, (6) self-confident, creative and never give up, (7) fair and spirited leadership, (8) good and humble, and (9) tolerant and peace-loving.

Character education is more important than moral education. This is because education is not the only character that deals with the problem of right and wrong, but how to inculcate the habit of the good things in life. As a result, a child has high awareness, understanding, respect, and a commitment to apply the virtues in everyday life. Character is the nature of a person to respond to the moral situation which is realized in concrete actions through good behavior, honesty, responsibility, respect for other people and others. In the context of Islamic thought, the term moral character is directly related to faith, charity and good deeds. It is also in line with Aristotel who states that character is closely related to the habits which is practiced continuously.

Law of 20 which has been launched in 2003 on National Education System in Article 3 , states that:

"National education serves to
develop skills and shape the


character and civilization of a dignified nation in the context of the intellectual life of the nation. National education aims at developing students' potentials in order to be a man who is faithful and devoted to God Almighty, noble, healthy, knowledgeable, skilled, creative, independent, and become citizens of a democratic and accountable. "

In accordance with the national education goals, the dimension of faith and increasingly devout and noble is an integral part. That is, to implant the noble character, love of peace, to be honest, responsible and good behavior, is not only the duty of a particular field or activity but also all parties must be involved. Thus, education as an integrated system should be systematically directed to form the character of human beings.

Education is the process of behavioral change which is based on the cultural values of the nation, religion, and local culture, as well as the development of learners potential. Meanwhile, in view of the general character, disposition, morals, or personality that is created from the internalization of the various policies are believed and used as the basis for perspective thinking and acting. Character education is a business of inculcating good habits, so that learners are able to behave and act based on the values of everyday life. Islam also teaches character values. The values contained in the Qur'an deals with commendable morals (to be done) and reprehensible character (to be avoided). Morality is, among other things: good treatment, compete in doing good, good speech, facial glow. While the reprehensible character includes: bad manners, hurry dopinions haste, cowardly, words that do not match the works.

Character education should be developed at school. In an effort to improve the relevance and quality of character education, the Ministry of Education and Culture has developed a character education grand design for each line, levels and types of education units. The design is supposed to be a conceptual and operational reference for development, implementation and assessment at every point and level of education. The reference figured out in the character within the context of total psychological and socio-cultural descriptions are grouped as follows: (1) Spiritual and emotional development. Healthy life leads to spiritual and emotional management; (2) Intellectual development which comes down to the management of intellectual thought; (3) Physical and kinesthetic development, exercise leads to physical management, and (4) affective and creativity development, though the taste comes down to managing creativity.

Lickona (1991) proposes three components of good character including (1) moral knowledge, (2) sense of morality, and (3) moral action. These three components need to be in character education, so that learners recognize, understand, feel and practice in everyday life virtues completely and thoroughly.

Three principles outlined above should serve as foundation in determining the success of character education. (1) the character education should contain values that may form a good character; (2) the character should be defined as a whole which includes the aspect of thinking, feeling and action; (3) the effective character education requires a comprehensive approach which is in the aspects of the teacher as a role model, school discipline, curriculum, learning, classroom management and school management, integration of material character in all aspects of classroom life, the cooperation of parents, communities and so on; (4) education should be a model community of peace and harmony; (5) to develop character, students need opportunities to practice; (6) effective character education must include a curriculum that is meaningful to the lives of children or competency-based (life skills) so that children have the ability to face and solve the problems of life; (7) character education should arise the internal motivation of the child; (8) the entire staff should be involved in character education. The role of head of the school is very big in mobilizing staff to be part 
of the process of character educationl; (9) character education at school requires moral leadership from the various parties; leadership, staff and teachers; (10) boarding schools should work with parents and the surrounding community, and; (11) there should be regular evaluation of the success of character in school.

In line with these eleven points, Lickona suggests that the implementation of this strategy should be more focused on character education to teachers and the school environment. For teachers, things to do in class are: (1) acting as a source of attention, a model and a mentor. (2) creating a moral society class, (3) moral discipline, by applying classroom rules with the gains as reward or punishment, (4) creating a democratic environment in the classroom, a way to involve students in a variety of decisionmaking, (5) teaching moral values through the curriculum, using the subject matter as a means of examining various moral dilemmas, (6) inviting students to learn to work together, (7) developing a work ethic, encouraging learners to have academic responsibility, and respect the value of work and study, (8) inviting students to hold a moral reflection, through reading, writing, discussion, practice making decisions and debates, (9) teaching conflict resolution. Meanwhile, outside the classroom, school are expected to: (a) develop an attitude of caring beyond the classroom, provide a model of behavior and conduct social services to the community, (b) create a moral culture in the islamic school, and (c) engage the parents and community and business community in strengthening the values taught by the school.

\section{THE PRINCIPAL ROLE CHARACTER EDUCATION}

The process of planting the values not only through formal and non-formal education, but also along with the development of science and technology, education undergoing a paradigm shift that had been confined to the classroom and school, but this time could occur outside the classroom through other educational media, both mass media, print and electronic. From electronic media include the visual and audiovisual. The diversity of the media presentation of the model has taken an important role in education Learning resources not only from educators (types of people), but could also others, such as certain types of messages, namely teaching or information to be learned or received by learners. Message form the content of the teaching and upbringing that is in the curriculum set forth by the teacher or other source into symbols of communication, both verbal (words spoken or written) or nonverbal or visual symbols (Moh. Raqib, 2009: 70).

A principal must exhibit leadership. This is a characteristic that every principal must possess. The principal is the instructional leader of their building. A good leader has to take responsibility both in the successes and the failures of their school. A good leader puts the needs of others in front of their own needs. A good leader is always looks to improve their school and then figures out how to make those improvements no matter how difficult it might be. Leadership defines how successful any school is. A school without a leader will likely fail, and a principal who is not a leader will find themselves without a job quickly.

The process of education has not yet managed to build Indonesia's human character. Education policy in Indonesia is also more concerned with aspects of intelligence. Most children of school (80\%-90\%) can not follow the curriculum in schools. Ranking system has been "convicted" of children who do not enter "10", as the children who are less intelligent. Such systems certainly negatively affect efforts to build character. Pain is not able to be prolonged form that does not personally believe in older people. It will lead to prolonged stress. During his youth, typically this situation will encourage teens to behave negatively.

This reality departs from the fundamental problem such as 1) why do not many students and educational output in Indonesia reflects the character (personality morality)?, and 2) What are the responsibilities of schools, communities, and families and solutions to educational institutions on the issue? 
Anti character issues in educational institutions is related to aspects of learning, education management and education units. Problems in daily learning activities are visible from unfresh school climate and learning process to fraud task, repetition and school exams.

The condition of implementation aspects of management education in schools based on the results of Asmendri's study (2011) on the implementation of management functions can be stated that on (1) aspects of educational planning during the process of goals setting and how to achieve them, and charge characters are clearly stated, because they are foundation of management activities, (2) organizational aspects, namely the delegation, coordinating tasks and utilization of resources to achieve the goals often cause problems, and (3) teaching materials delivered by the teachers tend to cognitive development, which is merely rote learning instead of directing to the formation of character in an integrated manner (Asmendri, 2011).

There are some identification of the constraints and problems of educational management. They are (a) the implementation of management education was less instilling values of science education; (b) there were inconsistencies between academic qualifications and functions of educators. Subjects such as biology teacher were also assigned to teach physics; (c) a shortage of teachers in certain areas, and an excess of teachers in other fields, (d) the school principal also makes additional hours of learning activities with a particular subject of his duty which was delegated to other teachers; (e) the principal of school/madrasah focused on student success in the "UN" so that students can perform in any way in examination. Although by deploying teachers to act contrary to its primary function which is allowing learners to cheat; and (f) cooperation with committee of school were not in harmony with the school committee.

The success or failures of educational institutions in the implementation of character education in schools or madrasah is determined by its leaders. The principal as a leader and educator in the school should be a model to all teachers and learners in the school. Prayitno (2010) suggests that the example should be part of the pillars of authority in the educational process. Exemplary is the culmination of the student teachers appearance. The whole appearance of educators is based on the acceptance and recognition, affection and tenderness, in the form of strengthening and educating wise act, which are entirely positive and normative. They are expected to be accepted and even imitated by learners. One thing is the key to the implementation of the exemplary obedience (consistency) looks educators with materials exemplary learners.

Achievement of the objectives of character education also depends on the skills and wisdom of leadership principals as managers who manage all the activities in the school. Good principals are the principals who are able to create a school climate characterized and provide a high job satisfaction for teachers or subordinates, and fun for all students. But how qualified leader is such a good manager?

Character education should be done in comprehensive and integral manners, whether at school, at home and community. With regard to the learning process, educators at educational units in the organization of learning materials can integrate intelligent character education into the subject matter being taught. To implement the character, such an educator must have the following conditions: (1) emulate the prophet, Muhammad (2) understand the principles of pattern, ie. starting from ourselves, (3) determine the character of educational stages. There are at least three stages of learning the characters, namely: (a) the stage of thinking to provide knowledge about the stage character, (b) phase of feeling, love is the stage and takes positive traits, and (c) stage act that impulses a strong self-learners to practice positive character traits manifested in everyday life.

The principal can play an important role in the process of character education in schools. In addition to the structural and administrative officials at the school, the principal also serves 
as supervisor oversight and guidance to the dynamics of the group of teachers, laboratory assistants, administrators, and staff of school. It is necessary to ensure the services generated within specifications or quality standards that have been set. Thus the head of the school play in the oversight function of both the process and learning outcomes as well as the supervision of the operative aspects of school management. Finally, the principal presents many colors to the development of a school; principal makes the different. (Wiyanto, 2007)

The principal is like the manager. The role of principal managerial is divided into three (Katz and Kahn in Lunenburg, 2000) namely: (1) technical, involving good planning, organizing, coordinating, supervising, and controlling techniques; (2) human, dealing with human relations and people skills, good motivating and morale building skills; and (3) conceptual, emphasizing technical knowledge and skills related to the service (or product) of the organization. Meanwhile, Katz and Kahn (2004) divides management expertise to three major area: technical, involves planning, organizing, coordinating, monitoring, and surveillance techniques; human relations, related to human relationship and people skills, both motivating and excitement builds skills, and conceptual, enforce the knowledge and technical skills associated with the service (or product) of the organization. (For the principal knowledge, conceptual connoted the leadership or curriculum, instruction, teaching, and learning). Managerial skills necessary carry out managerial duties effectively.

The principal does not only serve as supervisors and managers. Wahjosumidjo (2001) identifies the role of the principal, namely: the principal as a formal officer, principals as managers, principals as leaders, and principals as educators. While E. Mulyasa (2003) draw on the principal's role to seven with abbreviations EMASLIM, the principal as: (1) educators, (2) manager, (3) administrators, (4) supervisor, (5) leader, (6) innovator, and (7) motivator.
Related to the role and functions of the principal, Supriadi (1999) formulates seven things more an attitude/behavior that the principal school should have in order to create a healthy school life, conducive and supportive school performance, namely: (1) has a vision clearly, (2) rely more collaborative approach, (3) responsive and proactive in responding to what is happening outside of school, (4) example and be consistent in enforcing the rules, (5) a lot of active and drops down (management by walking around), (6) gives a lot of social rewards, and (7) create a variety of rides or activities that can develop pro-social skills (pro-social skills), faith and devotion of students.

\section{CONCLUSION}

Character education should be done in a comprehensive and integral ways at the school/madrasah. With regard to the learning process, educators at educational units in the organization of learning materials can integrate character education into the subject matter being taught. To implement the character, such an educator must have the conditions to emulate the nature of Allah, understand the principles of pattern, ie starting from ourselves, and determine the character of educational stages.

The success or failures of educational institutions in the implementation of character education in schools and madrasah is determined by its leaders. The principal as a leader and educator in the school should be an example to all teachers and learners in the school. It can be said that in the hands of the head of school there lies successful and a failed implementation of character education. This means that the head of school should be a good role model in leading the school. A variety of behaviors that are not good will contribute to the poor that would significantly weaken the character of the people. Role model will create a healthy school life, conducive and supportive school performance. 


\section{REFERENCES}

Agus, D. (2003). Dicari Kepala Sekolah yang Kompeten.

(Online:http://artikel/adharma.htm/) diakses 20 Juni 2012.

Asmendri, (2011). Implementasi Manajemen Pendidikan di Madrasah Kabupaten Tanahdatar . (Laporan Penelitian). Batusangkar: STAIN Batusangkar Press.

Asmendri. (2008). Pengantar Studi Manajemen Pendidikan. Batusangkar: STAIN Batusangkar Press.

Character Education Parnership (CEP). (2010). The Eleven Principles of Effective Character Education. (file:///D: Pendidikan\%20Karakter/ElevenPrincipl es-new2010.pdf) diakses 5 Juni 2014.

Dedi Supriadi. (1999). Mengangkat Citra dan Martabat Guru. Yogyakarta: Adicita Karya Nusa.

Fred C L. and Allan C, O. 2000. Educational Administration; Concepts and Practices.USA: Wadsworth.

http://artikel/adharma.htm/) diakses 20 Juni 2012.

Husaini, Adian, (2010) Pendidikan Islam Membentuk Manusia Berkarakter \& Beradab, Jakarta: Cakrawala publishing.

Jalal, F. \& Dedi Supriadi (editor). 2001. Reformasi Pendidikan dalam Conteks Otonomi Daerah. Yogyakarta: Adicita Karya Nusa.

Lickona, Thomas. (1991). Educating for Character: How our School can Teach Respect and Responsibility. New York: The New York Times Company.

Lickona, Thomas. (1991). Educating for Character: How our School can Teach Respect and Responsibility. New York: The New York Times Company.
Lickona, Tom, dkk. (1995). The Eleven Principles of Effective Character Education. Character Education Parnership (CEP): Washington. D.C.

Lunenburg, F. C. and Allan C. O. (2000). Educational Administration; Concepts and Practices.USA: Wadsworth.

Mulyasa, E. (2003). Menjadi Kepala Sekolah Profesional dalam Konteks Menyukseskan $M B S$ dan KBK. Bandung: PT Remaja Rosdakarya.

------.(2003). Menjadi Kepala Sekolah Profesional dalam Konteks Menyukseskan $M B S$ dan KBK. Bandung: PT Remaja Rosdakarya.

(2011). Manajemen Pendidikan Karakter. Jakarta: Bumi Aksara.

(2011). Manajemen Pendidikan Karakter. Jakarta: Bumi Aksara.

Permendiknas No. 13 Tahun 2007. tentang Kompetensi profesional kepala sekolah/madrasah.

Permendiknas No.28 Tahun 2010. tentang Penugasan Guru Menjadi kepala sekolah/madrasah.

Prayitno. (2010). Pendidikan Karakter Dalam Pembangunan Bangsa. Medan: PPs Universitas Negeri Medan.

Reinhartz. J. \& Don M. B. (2004). Educational Leadership: Changing schools, changing roles. USA: Pearson.

Roqib, M. (2009). Ilmu Pendidikan Islam, Pengembangan Pendidikan Integratif di Sekolah, Keluarga, dan Masyarakat, Yogyakarta: LKiS.

Supriadi, D. (1999). Mengangkat Citra dan Martabat Guru. Yogyakarta: Adicita Karya Nusa. 
Suyud. Peran Sentral Kepala Sekola dalam Penjaminan Mutu Pendidikan di Sekolah : Telaah Konseptual Pentingnya Penjaminan Mutu Pendidikan di Sekolah. (Online tersedia di http://artikel/suyud.htm/) Diakses 2 Mei 2012.

Wahjosumidjo. (2005). Kepemimpinan Kepala Sekolah: Tinjauan Teoritik dan Permasalahannya. Jakarta: PT RajaGrafindo Persada

Wiyanto. (2007). Supervisi Pendidikan IPA Bercirikan Dialog Profesional Kesejawatan dalam Konteks Pelaksanaan MBS. Jurnal Lembaran Ilmu Kependidikan jilid 36, no. 1, juni 2007. 